\title{
Deletion in the uridine diphosphate glucuronyltransferase 2B17 gene is associated with delayed pubarche in healthy boys
}

\author{
Annette Mouritsen ${ }^{1,2}$, Alexander Siegfried Busch ${ }^{1,2}$, Lise Aksglaede ${ }^{1,2}$, Ewa Rajpert-De Meyts ${ }^{1,2}$ and \\ Anders Juul1,2 \\ ${ }^{1}$ Department of Growth and Reproduction, Rigshospitalet, University of Copenhagen, Copenhagen, Denmark \\ ${ }^{2}$ International Center for Research and Research Training in Endocrine Disruption of Male Reproduction and Child Health (EDMaRC), Rigshospitalet, \\ University of Copenhagen, Copenhagen, Denmark \\ Correspondence should be addressed to A S Busch: alexander.siegfried.busch@regionh.dk
}

\begin{abstract}
Objective: Only a few genetic loci are known to be associated with male pubertal events. The ability of excreting testosterone $(\mathrm{T})$ and other steroids in the urine depends on sulfation and glucuronidation. One of several essential glucuronidases is encoded by the UGT2B17 gene. In a preliminary report, we found that homozygous deletion of UGT2B17 in boys was associated with lower urinary excretion of T. We hypothesized that boys with a lower glucuronidation capacity may have altered androgen action and excretion affecting pubarche, as this represents a T-dependent event. Design, participants and measures: 668 healthy boys (cross-sectional) aged 6.1-21.9 years (COPENHAGEN puberty study conducted from 2005 to 2006) were included. 65 of the boys where followed longitudinally every 6 months. Participants were genotyped for UGT2B17 copy number variation (CNV). Clinical pubertal staging including orchidometry, anthropometry and serum reproductive hormone levels. Results: 59 of the 668 boys (8.8\%) presented with a homozygous deletion of UGT2B17 (del/del). These boys experienced pubarche at a mean age of 12.73 years (12.00-13.46) vs 12.40 years (12.11-12.68) in boys heterozygous for deletion of UGT2B17 (del/ins) vs 12.06 years (11.79-12.33) in boys with the wild-type genotype (ins/ins) $(P=0.029$, corrected for BMI $z$-score). The effect accounted for 0.34 years delay per allele $(95 \% \mathrm{Cl}$ : $0.03-0.64)$. A comparable trend was observed for onset of testicular enlargement $>3 \mathrm{~mL}$ but did not reach significance.

Conclusion: CNV of UGT2B17 is a factor contributing to the timing of male pubarche.
\end{abstract}

\author{
Key Words \\ - pubarche \\ - UGT2B17 \\ - male \\ - puberty
}

\section{Introduction}

Testosterone ( $\mathrm{T}$ ) promotes maturation of the male reproductive organs, development of secondary sex characteristics and production of sperm by the testes. In puberty in boys, pulsatile gonadotropin stimulation upon reactivation of the hypothalamic-pituitary-gonadal axis results in testicular enlargement $>3 \mathrm{~mL}$ and secretion of $\mathrm{T}$ produced by the testicular Leydig cells (gonadarche). Furthermore, gradually increasing secretion of androgens including $\mathrm{T}$ produced by the adrenal glands is occurring from mid-childhood (adrenarche) resulting in pubic hair development (pubarche). T exerts its effects by binding to the androgen receptor (AR). Activation of the AR by $\mathrm{T}$ binding may vary and depends on the free biologically active $\mathrm{T}$ concentration. Thus, the biological activity of circulating $\mathrm{T}$ depends on the concentration of total $\mathrm{T}$, albumin and sex hormone-binding globulin (SHBG),

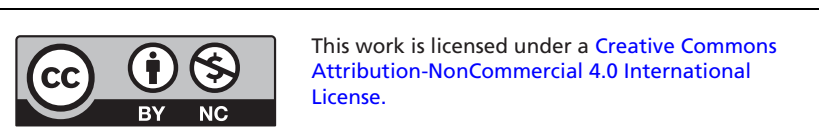


the transendothelial transport to target tissues, as well as the peripheral conversion rate of $\mathrm{T}$ into Estradiol (E2) and dihydrotestosterone (DHT). Finally, T concentration depends on the clearance rate, determined by, conversion of $\mathrm{T}$ to its metabolites, conjugation capacity, as well as urinary excretion. The ability of excreting $\mathrm{T}$ and other steroids in the urine depends on sulfation and glucuronidation of steroids to water-soluble conjugates. One of the several essential glucuronidases is uridine diphosphate glucuronyltransferase 2B17, encoded by the UGT2B17 gene, and several studies observed a lower urinary excretion of $\mathrm{T}$ with unaltered or higher level in the blood in males with homozygous $\operatorname{UGT2B17}(1,2,3)$. In a pilot study, we observed a significantly reduction of the urinary T:epitestosterone (E) ratio in UGT2B17 del/del boys, but without lower concentration of $\mathrm{T}$ in the blood (4). In vitro studies have suggested an inverse association between the level of UGT2B17 and the level of DHT (and other T metabolites) in local tissues (5).

We hypothesize that boys with lower glucuronidation of T due to a homozygous UGT2B17 deletion have altered $\mathrm{T}$ clearance, which may consequently influence the age at which boys develop androgen-dependent pubic hair.

\section{Materials and methods}

\section{Subjects}

Healthy boys (668 boys from 6.1 to 21.9 years of age) participating in the cross-sectional COPENHAGEN Puberty Study were included in the study $(6,7)$. Of the 668 included boys, 65 were followed every six months for five years (2006-2010, median (range) 11 (2-15) visits per boy) in the longitudinal part of the study $(6,7)$. Other aspects of this study have previously been published $(4,8,9,10,11,12)$. The Copenhagen Puberty Study was approved by the local ethical committee (Videnskabsetiske Komité for Region Hovedstaden, \# KF 01282214 and \# V200.1996/90). The study is registered in ClinicalTrials. gov (NCT01411527).

Consent has been obtained from each participant and parents after full explanation of the purpose and nature of all procedures used.

\section{Clinical examination}

Pubertal stages were evaluated by clinical examination according to Marshall and Tanner $(13,14)$. All evaluations of puberty in boys were performed by one of 3 male pediatricians. Testicular volume (TV) was measured by

$$
\text { http://www.endocrineconnections.org }
$$

palpation to the nearest mL using Prader's orchidometer. In case of discrepancy between left and right side, the largest measurement was used for classification. Assessment of pubic hair staging was done by inspection. Onset of testicular enlargement was defined as development testicular volume $>3 \mathrm{~mL}$ (TV $>3 \mathrm{~mL}$ ). Pubarche was defined as pubic hair $(\mathrm{PH})$ stage $\geq \mathrm{PH} 2$. Pubertal onset was defined as $\mathrm{TV}>3 \mathrm{~mL}$ or pubic hair stage $>\mathrm{PH} 2$.

Age at onset of pubic hair ( $\mathrm{PH} 2+)$ or testis volume $>3 \mathrm{~mL}$ was assigned as the mean age between age at the first examination in stage 2 or $>3 \mathrm{~mL}$ and the latest examination in stage 1 or $\leq 3 \mathrm{~mL}$, respectively.

\section{Genotyping}

DNA was isolated from peripheral blood using a semiautomatic nucleic acid isolation method, either on a QuickGene-810 apparatus (Fujifilm, Life Science Products, Tokyo, Japan) or Maxwell-16 (Promega Biotech AB), and quantified on a NanoDrop ND-1000 spectrophotometer (Saveen Werner AB, Malmö, Sweden). The analysis of UGT2B17 copy number variation (CNV) was performed by quantitative PCR on the Mx3000P platform (Stratagene, Cedar Creek, TX, USA), using primers specific for UGT2B17 and for the internal normalization gene GAPDH, as previously described in details (4).

\section{Hormone analyses}

Blood samples were drawn between 8:00 h and 10:00 h. The samples were clotted, centrifuged and serum was stored at $-20^{\circ} \mathrm{C}$ until hormone analyses were performed.

Serum FSH and LH were measured by time-resolved immunofluorometric assays (Delfia; PerkinElmer) with detection limits of 0.06 and $0.05 \mathrm{IU} / \mathrm{L}$ for $\mathrm{FSH}$ and $\mathrm{LH}$, respectively. Intra- and inter-assay coefficients of variation $(\mathrm{CV})$ were less than $5 \%$ in both gonadotropin assays. Estradiol levels were determined by RIA (Pantex, Santa Monica, CA, USA) with detection limit of $18 \mathrm{pmol} / \mathrm{L}$ and the intra- and inter-assays CV were $7.5 \%$ and $12.3 \%$ respectively. SHBG was determined buy a time-resolved immunofluorescence assay (Delfia; Wallac Oy, Turku, Finland) with a detection limit of $0.20 \mathrm{nmol} / \mathrm{L}$. Intra- and inter-assays CV were $5.8 \%$ and $6.4 \%$ respectively.

DHEAS, adione (androstenedione) and $\mathrm{T}$ in serum were quantified using a validated TurboFlow-LC-MS/MS method (15). The Adione:DHEAS ratio was calculated as adione (nmol/L) divided with DHEAS (nmol/L). Relative standard deviations for the quality control samples at the low and high concentration levels, respectively in that 
period were: DHEAS, $7.1 \%$ and $8.3 \%$; adione, $11.0 \%$ and $11.1 \%$ and $\mathrm{T}, 10.0 \%$ and $5.7 \%$. Limits of quantification (LOQ) were determined according to the International Conference on Harmonisation guidelines (ICH, 2005) and were DHEAS, $48 \mathrm{nmol} / \mathrm{L}$; adione, $0.18 \mathrm{nmol} / \mathrm{L}$ and $\mathrm{T}$, $0.10 \mathrm{nmol} / \mathrm{L}$.

\section{Statistical analysis}

Data are resented as medians and 25 and 75 percentiles and as means and 95\% confidence interval (CI). For hormone levels below the LOQ, the LOQ divided by the square root of 2 was used.

In order to estimate the mean age $(95 \% \mathrm{CI})$ at pubertal onset, we performed probit analyses (SAS; proc lifereg). This allowed integration of left-, right- and interval-censored observations and pubic hair status (PH2+) or testis volume $>3 \mathrm{~mL}$, yes/no as a binomial response variable. Longitudinal data of boys entering puberty during follow-up was included in the probit analyses (interval censored data). If a boy entered puberty between two examinations, the date between these examinations was used as interval-censored data. If a boy had not entered puberty at his last examination (or only examination if seen once), his age at examination was used as right censored data. If a boy had entered puberty at his first examination, his age at examination was used as left censored data.

The cohort was standardized by applying WHO agespecific body mass index scores (BMI z-scores) (16). As longitudinal data were available in 65 boys, we calculated a mean of all individual BMI z-scores. Comparisons of hormone levels between groups were carried out using GLM Univariate using the SPSS software (version 19; SPSS). In the probit analyses, age at pubertal onset was adjusted for BMI $z$-score. Examinations above the age of 19 years $(n=18)$ were not included into the analysis of pubertal onset, as the WHO age-specific body mass index scores is not specified for this age.

A $P$ value $\leq 0.05$ was considered statistically significant.

\section{Results}

Approximately one out of ten boys presented with the homozygous deletion of the UGT2B17 (del/del): 59 of the 668 boys in the cross-sectional study (8.8\%) and 6 of the 65 boys in the longitudinal study (9.2\%) (Table 1$)$. Irrespective of UGT2B17 genotype, mean age at testicular enlargement $>3 \mathrm{~mL}$ was 11.65 years (11.51-11.80, non-corrected) and 11.76 (11.62-11.90, corrected for BMI $z$-score) while mean age at pubarche was 12.16 (11.96-12.36; non-corrected) and 12.26 (12.06-12.46, corrected for BMI z-score) (Fig. 1).

Pubic hair developed at a later age in boys with the UGT2B17 del/del genotype compared to the boys who were heterozygous and homozygous carriers of the UGT2B17 gene (del/ins) and (ins/ins). The UGT2B17 $\mathrm{del} /$ del boys experienced pubarche ( $\mathrm{PH} 2+)$ at a mean age of 12.73 years (12.00-13.46) compared to a mean age of 12.40 (12.11-12.68) in boys with the del/ins and a mean age of 12.06 (11.79-12.33) in boys with the ins/ins when corrected for BMI $z$-score $(P=0.029)$. The effect accounted for 0.34 years delay per allele (95\% CI: 0.03-0.64). The comparisons were also statistical significant without correction for zBMI $(P=0.043$; effect size: 0.32 years per allele; 95\% CI: 0.00-0.65). Table 1 illustrates age at PH2+ in all three groups, with and without BMI z-score correction.

Although not statistically significant with and without BMI $z$-score correction (Table 1), we observed a later onset of testicular enlargement $>3 \mathrm{~mL}$ in the boys with the homozygote deletion compared to the boys with the ins/del and the ins/ins genotype (12.09 years (11.54-12.64) vs 11.79 (11.58-11.99) and 11.69 years (11.50-11.89);

Table 1 Age, zBMI, age at pubertal onset PH2+ (pubarche) and TV (testicular volume) $>3 \mathrm{~mL}$ stratified by UGT2B17 genotype.

\begin{tabular}{l} 
UGT2B17 genotype \\
\hline Median age in yrs (25th and \\
75th percentile) \\
Median zBMI (25th and \\
75 th percentile) \\
Mean age at $\mathrm{PH}+$ in yrs $(95 \% \mathrm{Cl})$ \\
No correction \\
Corrected for zBMI \\
Mean age at TV $>3 \mathrm{~mL}$ in yrs $(95 \% \mathrm{Cl})$ \\
No correction \\
Corrected for $z \mathrm{BMI}$
\end{tabular}

$\frac{\text { del/del }(n=59)}{11.38(8.56-14.83)}$
$0.20(-0.63$ to 0.98$)$

$12.65(11.89-13.41)$

$12.73(12.00-13.46)$

$12.08(11.49-12.67)$

$12.09(11.54-12.64)$

n, number; yrs, years.

\begin{tabular}{|c|c|c|}
\hline del/ins $(n=309)$ & ins/ins $(n=300)$ & $P$ value \\
\hline $11.23(9.16-14.05)$ & $11.14(9.27-13.62)$ & \\
\hline $0.35(-0.24$ to 0.97$)$ & $0.23(-0.41$ to 0.91$)$ & \\
\hline $12.28(11.99-12.57)$ & $11.97(11.68-12.25)$ & $P=0.043$ \\
\hline $12.40(12.11-12.69)$ & $12.06(11.79-12.33)$ & $P=0.029$ \\
\hline 11.65 (11.44-11.86) & $11.60(11.39-11.81)$ & $P=0.253$ \\
\hline 11.79 (11.58-11.99) & 11.69 (11.50-11.89) & $P=0.204$ \\
\hline
\end{tabular}

(๔) 2018 The authors Published by Bioscientifica Ltd http://www.endocrineconnections.org https://doi.org/10.1530/EC-18-0080

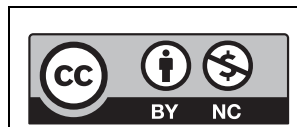

This work is licensed under a Creative Commons Attribution-NonCommercial 4.0 International License. 


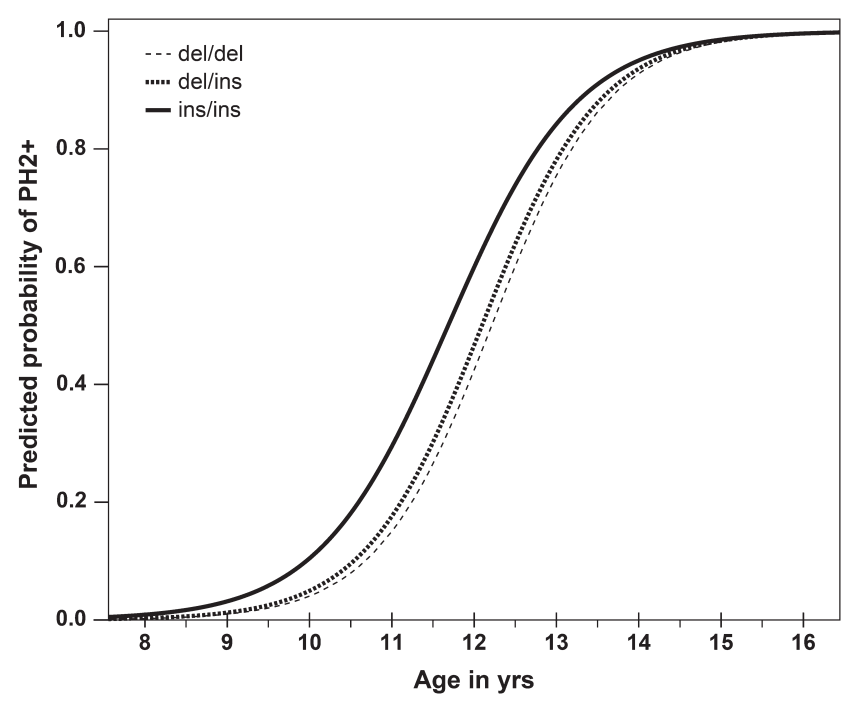

Figure 1

Predicted probability of age at $\mathrm{PH} 2+$ (onset of pubic hair Tanner stage 2) stratified by UGT2B17 genotype.

$P=0.204$; corrected for BMI $Z$-score). Comparing the $\mathrm{del} / \mathrm{del}$ as one group to the del/ins and ins/ins as another group did not result in a significant later age at TV $>3 \mathrm{~mL}$.

The hormones FSH, E2, LH, T, DHEAS and adione increased with age and puberty, and SHBG decreased. No significant differences in hormone levels of FSH, E2, LH, T, SHBG, DHEAS or adione between groups corrected for age were observed (data not shown).

Although not statistically significant, we observed a higher level of DHEAS and a lower level of Adione. Analyzing the adione:DHEAS ratio corrected for age, we observed a significant lower level in the boys with the UGT2B17 del/del $(P=0.014)$.

\section{Discussion}

This is the first demonstration of delayed pubarche in boys carrying a common deletion of the UGT2B17 gene, which codes for an enzyme involved in urinary steroid excretion.

Knowledge is sparse regarding the genetic etiology of the timing of male pubertal events. However, recent research points to the fact that beside classical genes involved in central reactivation of the hypothalamicpituitary-gonadal axis, also genes exerting an effect on peripheral target tissue are significantly associated with the occurrence of pubertal events $(17,18)$. We found deletion of UGT2B17 to be significantly associated with pubarche but not with testicular enlargement $>3 \mathrm{~mL}$.
The impact of UGT2B17 genotype on age at pubarche but not age at onset of testicular growth is in line with the assumption of an altered $\mathrm{T}$ action by UGT2B17 affecting pubarche, a testosterone-dependent event, but not testicular enlargement, which is a gonadotropindependent event (19). Further, our findings of an association of the UGT2B17 deletion with delayed pubarche highlight a potential role of this CNV in ethnic differences in timing of pubertal events. As the deletion is relatively rare among Caucasians and very frequent among Asians $(1,2)$, it is intriguing that although in Chinese boys testicular enlargement $>3 \mathrm{~mL}$ occurs more than a year earlier compared to the Danish boys of our present study, pubarche occurs later in Chinese boys than in Danish boys (TV>3: 10.55 vs 11.65 years; PH2+: 12.78 vs 12.16 years, respectively) (20). We speculate that the frequency of the UGT2B17 deletion may contribute to ethnic differences in age at pubarche.

The observed prevalence of $10 \%$ of boys being homozygote for the UGT2B17 deletion is in accordance with the prevalence in other studies of Caucasian boys $(1,4,21)$.

In our pilot study, we found no difference in the serum concentration of $\mathrm{T}$, but only in the urinary concentration of $\mathrm{T}$ (4). In vitro studies in prostatic cancer cells have revealed that both $U G T 2 B 15$ and $U G T 2 B 17$ are critical enzymes for the local inactivation of androgens (5). The circulating $\mathrm{T}$ is converted to DHT, a potent androgen receptor agonist, by $5 \alpha$-reductase. As it is extremely important to modulate DHT levels locally, the substrates (DHT, 3 $\alpha$-DIOL and ADT) are regulated by steroidogenic enzymes and glucuronidation. Furthermore, it seems as an impaired clearance of $\mathrm{T}$ is regulated by a lower production of $\mathrm{T}$ to keep the serum level in a steady state. The lower production could be due to the conversion of precursors through other pathways than the adione to T pathway. As observed the boys with the UGT2B17 del/del had a lower adione:DHEAS ratio, indicating that the conversion of DHEAS to adione could be impaired.

Although some studies have observed associations between the deletion polymorphism of UGT2B17 with osteoporosis in males (2), prostate cancer (22), lower incidence of colorectal cancer in males (23), other studies observed no association with osteoporosis risk (24) or with risk of prostate cancer (25). A recent CNV study found that the UGT2B gene deletions are very common and may indicate that the effects are neutral or minor (26). The UGTB15 substitutes for UGT2B17 and other genes may have a compensatory role in the UGT activity.

$$
\text { http://www.endocrineconnections.org }
$$

https://doi.org/10.1530/EC-18-0080 (c) 2018 The authors Published by Bioscientifica Ltd
This work is licensed under a Creative Commons Attribution-NonCommercial 4.0 International License. 


\section{Conclusion}

UGT2B17 is involved in the timing of male pubarche. The boys with the homozygous deletion experienced delayed pubic hair development, although circulating T, DHEAS and androstenedione did not differ between genotype groups. UGT2B17 may contribute to the differential timing of male pubertal events across ethnicities.

\section{Declaration of interest}

The authors declare that there is no conflict of interest that could be perceived as prejudicing the impartiality of the research reported.

\section{Funding}

Danish Agency for Science, Technology and Innovation (09-067180); Danish Ministry of the Environment, CeHoS (MST-621-00065); Capital Region of Denmark (R129-A3966); Ministry of Higher Education and Science (DFF1331-00113); The Innovation Fund Denmark (InnovationsFonden, 142013-4); The International Center for Research and Research Training in Endocrine Disrupting Effects of Male Reproduction and Child Health (EDMaRC).

\section{References}

1 Jakobsson J, Ekstrom L, Inotsume N, Garle M, Lorentzon M, Ohlsson C, Roh HK, Carlstrom K \& Rane A. Large differences in testosterone excretion in Korean and Swedish men are strongly associated with a UDP-glucuronosyl transferase 2B17 polymorphism. Journal of Clinical Endocrinology and Metabolism 200691 687-693. (https://doi.org/10.1210/jc.2005-1643)

2 Yang TL, Chen XD, Guo Y, Lei SF, Wang JT, Zhou Q, Pan F, Chen Y, Zhang ZX, Dong SS, et al. Genome-wide copy-number-variation study identified a susceptibility gene, UGT2B17, for osteoporosis. American Journal of Human Genetics 200883 663-674. (https://doi. org/10.1016/j.ajhg.2008.10.006)

3 Zhu AZ, Cox LS, Ahluwalia JS, Renner CC, Hatsukami DK, Benowitz NL \& Tyndale RF. Genetic and phenotypic variation in UGT2B17, a testosterone-metabolizing enzyme, is associated with BMI in males. Pharmacogenetics and Genomics 201525 263-269. (https://doi.org/10.1097/FPC.0000000000000135)

4 Juul A, Sorensen K, Aksglaede L, Garn I, Rajpert-De Meyts E, Hullstein I, Hemmersbach P \& Ottesen AM. A common deletion in the uridine diphosphate glucuronyltransferase (UGT) $2 \mathrm{~B} 17$ gene is a strong determinant of androgen excretion in healthy pubertal boys. Journal of Clinical Endocrinology and Metabolism 200994 1005-1011. (https://doi.org/10.1210/jc.2008-1984)

5 Chouinard S, Barbier O \& Belanger A. UDP-glucuronosyltransferase 2B15 (UGT2B15) and UGT2B17 enzymes are major determinants of the androgen response in prostate cancer LNCaP cells. Journal of Biological Chemistry 2007282 33466-33474. (https://doi. org/10.1074/jbc.M703370200)

6 Aksglaede L, Sorensen K, Petersen JH, Skakkebaek NE \& Juul A. Recent decline in age at breast development: the Copenhagen Puberty Study. Pediatrics 2009123 e932-e939. (https://doi. org/10.1542/peds.2008-2491)

7 Sorensen K, Aksglaede L, Petersen JH \& Juul A. Recent changes in pubertal timing in healthy Danish boys: associations with body mass index. Journal of Clinical Endocrinology and Metabolism 201095 263-270. (https://doi.org/10.1210/jc.2009-1478)
8 Aksglaede L, Sorensen K, Boas M, Mouritsen A, Hagen CP, Jensen RB, Petersen JH, Linneberg A, Andersson AM, Main KM, et al. Changes in anti-Mullerian hormone (AMH) throughout the life span: a population-based study of 1027 healthy males from birth (cord blood) to the age of 69 years. Journal of Clinical Endocrinology and Metabolism 201095 5357-5364. (https://doi.org/10.1210/jc.20101207)

9 Hagen CP, Aksglaede L, Sorensen K, Mouritsen A, Andersson AM, Petersen JH, Main KM \& Juul A. Individual serum levels of antiMullerian hormone in healthy girls persist through childhood and adolescence: a longitudinal cohort study. Human Reproduction 2012 27 861-866. (https://doi.org/10.1093/humrep/der435)

10 Mieritz MG, Frederiksen H, Sorensen K, Aksglaede L, Mouritsen A, Hagen CP, Skakkebaek NE, Andersson AM \& Juul A. Urinary phthalate excretion in 555 healthy Danish boys with and without pubertal gynaecomastia. International Journal of Andrology 201235 227-235. (https://doi.org/10.1111/j.13652605.2012.01279.x)

11 Mouritsen A, Aksglaede L, Soerensen K, Hagen CP, Petersen JH, Main KM \& Juul A. The pubertal transition in 179 healthy Danish children: associations between pubarche, adrenarche, gonadarche, and body composition. European Journal of Endocrinology 2013168 129-136. (https://doi.org/10.1530/EJE-12-0191)

12 Mouritsen A, Soeborg T, Johannsen TH, Aksglaede L, Sorensen K, Hagen CP, Mieritz MG, Frederiksen H, Andersson AM \& Juul A. Longitudinal changes in circulating testosterone levels determined by LC-MS/MS and by a commercially available radioimmunoassay in healthy girls and boys during the pubertal transition. Hormone Research in Paediatrics 201482 12-17. (https://doi. org/10.1159/000358560)

13 Marshall WA \& Tanner JM. Variations in pattern of pubertal changes in girls. Archives of Disease in Childhood 196944 291-303. (https:// doi.org/10.1136/adc.44.235.291)

14 Marshall WA \& Tanner JM. Variations in the pattern of pubertal changes in boys. Archives of Disease in Childhood 197045 13-23. (https://doi.org/10.1136/adc.45.239.13)

15 Soeborg T, Frederiksen H, Fruekilde P, Johannsen TH, Juul A \& Andersson AM. Serum concentrations of DHEA, DHEAS, 17alphahydroxyprogesterone, Delta4-androstenedione and testosterone in children determined by TurboFlow-LC-MS/MS. Clinica Chimica Acta 2013419 95-101. (https://doi.org/10.1016/j.cca.2013.01.019)

16 de Onis M, Onyango AW, Borghi E, Siyam A, Nishida C \& Siekmann J. Development of a WHO growth reference for school-aged children and adolescents. Bulletin of the World Health Organization 200785 660-667. (https://doi.org/10.2471/ BLT.07.043497)

17 Day FR, Bulik-Sullivan B, Hinds DA, Finucane HK, Murabito JM, Tung JY, Ong KK \& Perry JR. Shared genetic aetiology of puberty timing between sexes and with health-related outcomes. Nature Communications 20156 8842. (https://doi.org/10.1038/ ncomms9842)

18 Busch AS, Hagen CP, Main KM, Pereira A, Corvalan C, Almstrup K, Mericq V \& Juul A. Genetic variation of follicle-stimulating hormone action is associated with age at testicular growth in boys. Journal of Clinical Endocrinology and Metabolism 2017102 1740-1749. (https:// doi.org/10.1210/jc.2016-4013)

19 McLachlan RI, Wreford NG, O'Donnell L, de Kretser DM \& Robertson DM. The endocrine regulation of spermatogenesis: independent roles for testosterone and FSH. Journal of Endocrinology 1996148 1-9. (https://doi.org/10.1677/joe.0.1480001)

20 Ma HM, Chen SK, Chen RM, Zhu C, Xiong F, Li T, Wang W, Liu GL, Luo XP, Liu L, et al. Pubertal development timing in urban Chinese boys. International Journal of Andrology 201134 e435-e445. (https:// doi.org/10.1111/j.1365-2605.2011.01173.x)

21 Strahm E, Sottas PE, Schweizer C, Saugy M, Dvorak J \& Saudan C. Steroid profiles of professional soccer players: an international 
comparative study. British Journal of Sports Medicine 200943 1126-1130. (https://doi.org/10.1136/bjsm.2008.056242)

22 Karypidis AH, Olsson M, Andersson SO, Rane A \& Ekstrom L. Deletion polymorphism of the UGT2B17 gene is associated with increased risk for prostate cancer and correlated to gene expression in the prostate. Pharmacogenomics Journal 20088 147-151. (https:// doi.org/10.1038/sj.tpj.6500449)

23 Angstadt AY, Berg A, Zhu J, Miller P, Hartman TJ, Lesko SM, Muscat JE, Lazarus P \& Gallagher CJ. The effect of copy number variation in the phase II detoxification genes UGT2B17 and UGT2B28 on colorectal cancer risk. Cancer 2013119 2477-2485. (https://doi.org/10.1002/cncr.28009)
24 Chew S, Mullin BH, Lewis JR, Spector TD, Prince RL \& Wilson SG. Homozygous deletion of the UGT2B17 gene is not associated with osteoporosis risk in elderly Caucasian women. Osteoporosis International 201122 1981-1986. (https://doi.org/10.1007/s00198-010-1405-0)

25 Olsson M, Lindstrom S, Haggkvist B, Adami HO, Balter K, Stattin P, Ask B, Rane A, Ekstrom L \& Gronberg H. The UGT2B17 gene deletion is not associated with prostate cancer risk. Prostate 200868 571-575. (https://doi.org/10.1002/pros.20700)

26 Veerappa AM, Padakannaya P \& Ramachandra NB. Copy number variation of UGT 2B genes in Indian families using whole genome scans. Journal of Nucleic Acids 20162016 1648527. (https://doi. org/10.1155/2016/1648527)

Received in final form 18 February 2018

Accepted 21 February 2018

Accepted Preprint published online 21 February 2018 http://www.endocrineconnections.org https://doi.org/10.1530/EC-18-0080
(C) 2018 The authors Published by Bioscientifica Ltd

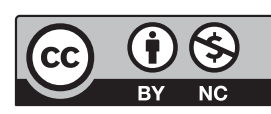

This work is licensed under a Creative Commons Attribution-NonCommercial 4.0 International License. 